\section{Thermodynamic, Environmental and Economic Simulation of an Organic Rankine Cycle (ORC) for Waste Heat Recovery: Terceira Island Case Study}

\author{
Lisandra ROCHA-MENESES ${ }^{1 *}$, Jose Carlos SILVA ${ }^{2}$, Sandra COTA $^{3}$, Timo KIKAS ${ }^{4}$ \\ ${ }^{1,4}$ Estonian University of Life Sciences, Institute of Technology, Kreutzwaldi 56, Tartu, 51006, Estonia \\ 2,3 Independent researcher, Terceira Island, Azores, Portugal
}

\begin{abstract}
The aim of this study is to analyse from the thermodynamic, environmental and economic point of view an ORC for heat recovery from urban waste, using $\mathrm{R245fa}$ as a working fluid on the example of Terceira Island (Azores). The proposed ORC system includes two evaporators, two turbines, a condenser, a pump and a generator. The thermodynamic model is created using the Visual Basic programming language. In order to analyse the influence of pressure, temperature and mass flow on net output, efficiency, and mass flow rate of the power plant, the sensibility analysis is carried out. The results show that from the energetic point of view, urban waste recovery (using an ORC) could be a viable solution on Terceira Island, since the maximum net output produced from this system for a mass rate of 19727 tonnes is $485 \mathrm{~kW}$. The efficiency of the ORC is $25 \%$. Environmentally, the incineration of the urban waste produced on the island is a positive solution for these residues since it will reduce the amount of waste deposited in the landfill. However, this project is not economically viable. The losses estimated in this study exceed 500000 EUR (per year).
\end{abstract}

Keywords - Circular economy; energy conversion; R245fa; thermal efficiency; waste to energy; zero-waste

\begin{tabular}{lll}
\hline Nomenclature & & \\
$\dot{m}$ & Mass flow rate & $\mathrm{kg} / \mathrm{h}$ \\
$\dot{Q}$ & Heat flow rate & $\mathrm{kW}$ \\
$\dot{W}_{\mathrm{n}}$ & Net power output & $\mathrm{kW}$ \\
$a$ & Financial discount factor & \\
Cond. & Conductivity & $\mu \mathrm{S} / \mathrm{cm}$ \\
FTE & Fuel to electricity ratio & \\
$h$ & Enthalpy & $\mathrm{kJ} / \mathrm{kg}$ \\
$m$ & Mass flow & $\mathrm{kg}$ \\
ORC & Organic Rankine Cycle & \\
$P$ & Pressure & $\mathrm{MPa}$ \\
$S$ & Cash flow balance & \\
\hline
\end{tabular}

* Corresponding author.

E-mail address: lisandra.meneses@emu.ee

(C2019 Lisandra Rocha-Meneses, Jose Carlos Silva, Sandra Cota, Timo Kikas.

This is an open access article licensed under the Creative Commons Attribution License (http://creativecommons.org/ licenses/by/4.0), in the manner agreed with Sciendo. 


\begin{tabular}{|lll|}
\hline SRC & Steam Rankine Cycle & \\
$T$ & Temperature & \\
$x$ & Vapour quality & \\
$C_{\mathrm{p}} \mathrm{C}$ & Specific heat & $\mathrm{kJ} / \mathrm{m}^{3}$ \\
LHV & Lower heating value & \\
Symbols & & \\
$\eta$ & Efficiency & \\
$v$ & Specific volume & \\
Subscripts & \\
$1-6$ & State points of the ORC working fluid & \\
E & Evaporator \\
$\mathrm{s}$ & Specific entropy & \\
$\mathrm{P}$ & Pump \\
$\mathrm{f}$ & Saturated liquid & \\
$\mathrm{g}$ & Saturated vapour & \\
$\mathrm{T}$ & Turbine \\
$\mathrm{t}$ & Time \\
in & Ingoing flow \\
$\mathrm{i}$ & State point \\
$\mathrm{n}$ & Net \\
$\mathrm{cyc}$ & Cycle & \\
\hline
\end{tabular}

\section{INTRODUCTION}

Industrialization, along with population growth, has been contributing to the increase in energy consumption worldwide. To cope with the demand, the energy supply has also increased. However, fossil fuels are still the primary source of energy used in the world, representing $82 \%$ of the primary energy consumption [1], [2]. Concerns have been raised regarding the availability and utilization of these sources of energy. Therefore, the European Union (EU) has established strategies to decrease greenhouse gas emissions to at least $20 \%$ lower than 1990 levels [3]. As a result, there is a search for reliable alternative sources of energy, that will replace fossil fuels in the final energy-mix, reduce emissions of $\mathrm{CO}_{2}$ into the atmosphere and decrease greenhouse gas emissions [4]-[6]. Heat technologies and combined heat and power production have been studied over the years, as promising solutions for waste heat recovery, as a way of decrease the emissions of $\mathrm{CO}_{2}$ into the atmosphere and reduce the number of residues deposited in the landfill. Technological advances allowed the transformation of waste in value added products (in a circular economy) [7]. ORC, Kalina cycle, Goswami cycle and supercritical carbon dioxide cycle are some of these technologies [8], [9].

Great attention has been paid to sustainable energy systems as ORC systems due to its relatively low costs, and potential for both heat and electricity production [9], [10]. This system involves the circular economy concept were waste is utilized as a feedstock for further 
heat or energy production, avoiding landfill investments, reducing the amount of waste, or even generating revenues, through the sale of energy [11]. The ORC is similar to a normal Rankine cycle operating with steam. However, ORC uses an organic compound as a working fluid, with a lower ebullition temperature than water, which allows power generation from low-temperature heat sources [12]. The selection of the appropriate working fluid is done according to the critical temperature, critical pressure, and boiling temperature at several pressures [13]. Working fluids can be classified into three categories (1) dry fluids - derived math of the $T$-S diagram curve is positive $(\mathrm{d} T / \mathrm{d} S)$; (2) isentropic fluids - derived math of the $T-S$ diagram curve is infinite $(\mathrm{d} T / \mathrm{d} S)$; (3) humid fluids - derived math of the $T-S$ diagram curve is negative $(\mathrm{d} T / \mathrm{d} S)$ [14].

The efficiency of the ORCs depends largely on the components of the system and on parameters such as temperature, pressure, and mass flow. The conceptual scheme of a basic ORC is composed of four main components: an evaporator, a condenser, a turbine expander and a pump, that have four main reversible steps: isentropic expansion, heat rejection, isentropic compression, and heat injection. In the isentropic expansion, the vapour drifts into the turbine and its enthalpy is transformed into work, used by the generator. Next, in the heat rejection stage, the vapour from the turbine is directed into the condenser where it is liquefied by cooling water. The isentropic compression consists of the pressurization (by the pump) of the liquid obtained at the condenser outlet and its flow into the evaporator. Finally, in the heat injection stage, the working fluid is heated and compressed (from low pressure to highpressure) by the heat source. After this, a new cycle starts [15], [16].

However, ORC still allows for a relatively low performance mainly due to the low temperatures in the evaporator [17]. A way to improve the energetic efficiency of the cycle is to change the configuration of the ORC and add more components to the system [10], [11]. Mago et al. [18] studied the performance of the ORC by adding a regenerative cycle to the system. The results show that this configuration gives higher efficiencies, lower irreversibility, and lower heat requirements. Two-stage ORC (combining reheat and superheat) has also been reported in the literature as an effective solution to increase the network output and the thermal efficiency of the cycle [19]. Wang et al. [17] investigated the potential of this technology to improve the performance of the ORC. The authors concluded that this configuration decreased irreversible losses, enhanced the evaporation temperature, and improved the efficiency of the cycle. Similar results have been reported by Li et al. [20] and Rech et al. [21]. Besides the performance, when it refers to the implementation and installation of cogeneration or combined heat and power, other factors should be considered. The technical and economic viability of the project should be insured even despite the amount of feedstock available, price of electricity or distribution to the grid. A solution to ensure a high efficiency of the system and a sustainable energy supply is the appropriate planning of the size and capacity of the cogeneration system [9]. This not only gives the optimum operating conditions for the system but also allows to achieve the maximum efficiency of the cycle using the local waste production.

This paper aims to model and simulate a thermodynamic model of an ORC combining reheat and superheat, for waste heat recovery in Terceira Island, Azores, Portugal. The proposed ORC system includes two evaporators, two turbines, a condenser, a pump and a generator. For this, the influence of pressure, temperature and mass flow on net output, efficiency, and mass flow rate of the power are analysed. The results are compared with the actual performance and efficiency of the local incinerator (fully operating since 2017), and suggestions to improve its performance are proposed. The study also takes into consideration the environmental and economic analysis of the project. 


\section{Case Study}

Terceira Island is the second biggest island of the Azores Archipelago (Autonomous Region of Portugal). It has 56141 inhabitants [22] and two municipalities (Angra do Heroísmo and Praia da Vitória), divided by civil parishes. The characterization of the production and consumption of energy in the island is presented in Fig. 1.

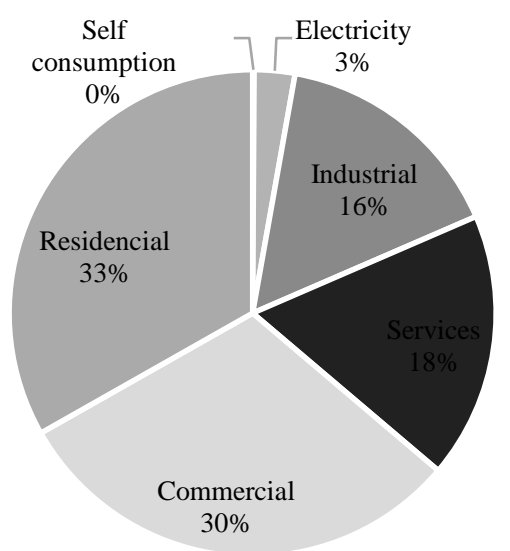

(a)

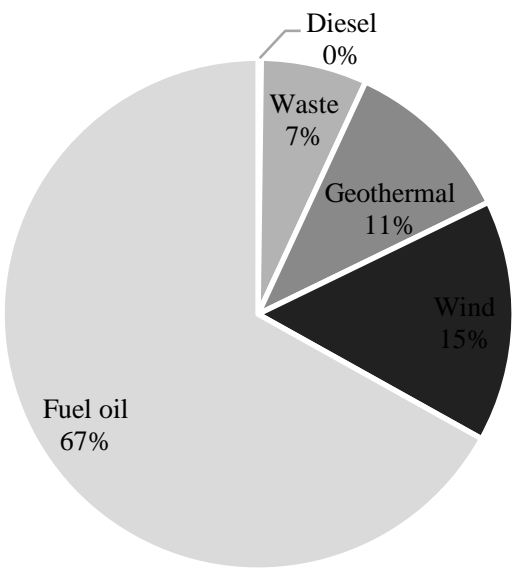

(b)

Fig. 1. Energy (a) consumption and (b) production in Terceira Island (2018) [23].

All the urban waste produced on the island goes to the local landfill. In 2017, the quantity of urban waste produced in Terceira Island was 33179 tonnes (Fig. 2). 


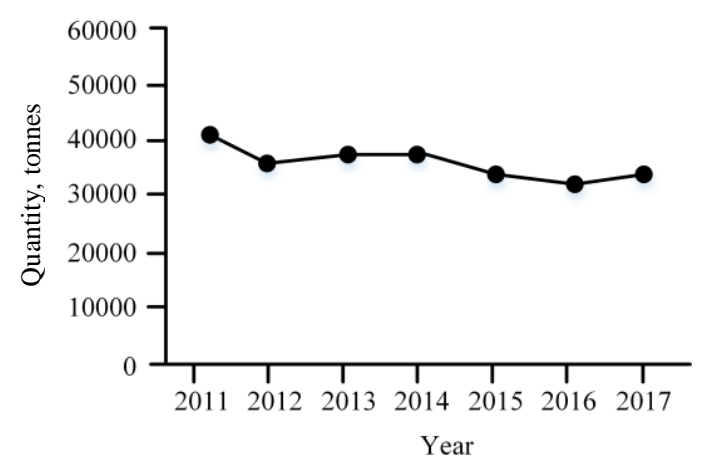

Fig. 1. Evolution of urban waste production in Terceira Island [24].

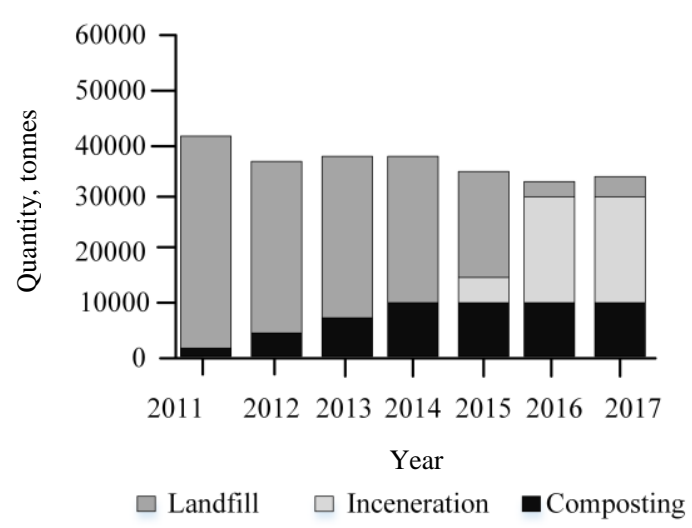

Fig. 2. The final destination of urban waste in Terceira Island between the years 2011-2016 [24].

From 2011 to 2014 the urban waste of the island had two final destinations: composting and landfill. In 2015 an incinerator was installed on the island, reducing drastically the number of residues deposited in the landfill, and increasing the number of recycled residues (Fig. 3). In 2017, 2638 tonnes of residues were deposited in the landfill, 9942 tonnes were utilized for composting and 20599 tonnes were energetically valorised in the local incinerator (built in 2015, fully operating since 2017 and with a capacity for 40000 tonnes).

\section{Methodology}

\subsection{Thermodynamic Modelling and Simulation}

The thermodynamic model used in this study (Fig. 4) is composed of two turbines, one generator, one condenser, one pump, and two evaporators. The working fluid employed in this research was R245fa. This set-up (combining reheat and superheat) was chosen mainly due to its well-known advantages. When compared with a simple ORC cycle, combined reheat and superheat improves the work output from the turbine, the steam quality and the cycle efficiency [25]. Also, research has shown that ORC has clearly a better performance when compared to Steam Rankine Cycle (SRC) (using water as the working fluid). It enables internal heat recovery, higher turbine efficiencies, and net power outputs [26]. R245fa was 
chosen as a working fluid because, when compared with refrigerants such as R11, R114 or R141b, it has zero Ozone Depletion Potential, lower global warming potential, low toxicity, and it is non-flammable [27]. In addition, certain disadvantages of the utilization of water as a working fluid have been reported in the literature. It is extremely corrosive and it has a relatively high freezing temperature [28].

The working principle of the ORC is the following. The liquid obtained from the condenser outlet is pumped to the evaporator I (1-2), where it is vaporized until it becomes superheated vapour (from position 2 to 3 ). In the turbine I, vapour from the evaporator I is expanded (position 3-4) and in the evaporator II, waste heat exchanges heat with the working fluid (R245fa) (position 4-5), which flows to the turbine II to do work, used by the generator (position 5-6). Exhausted stream from the turbine II enters the condenser and it is cooled down to saturated liquid (position 6-1).

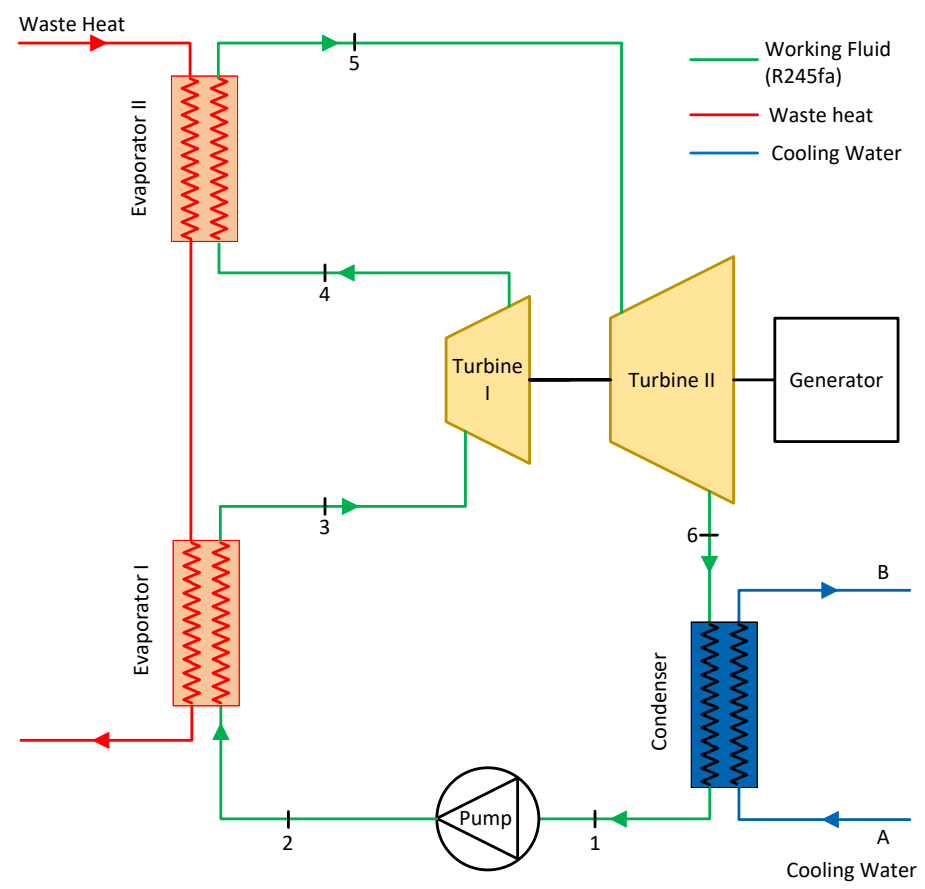

Fig. 4. ORC setup used in the thermodynamic simulation.

Table 1 illustrates the initial conditions used in the thermodynamic simulation.

TABle 1. Initial Conditions of THE THERMOdynamic MODEL

\begin{tabular}{lllllllll}
\hline$T_{\mathrm{A}}$ & $T_{\mathrm{B}}$ & $\eta_{\mathrm{T}}$ & $\eta_{\mathrm{P}}$ & $P_{1}$ & $P_{2}$ & $T_{3}$ & $P_{4}$ & $m$ \\
\hline 20 & 30 & 0.85 & 0.75 & 0.09 & 3.75 & 150 & 1 & 19727 \\
\hline
\end{tabular}

where $T_{\mathrm{A}}$ is the inlet temperature, $T_{\mathrm{B}}$ the outlet temperature, $\eta_{\mathrm{T}}$ the efficiency of the turbine, $\eta_{\mathrm{P}}$ efficiency of the pump, $P_{1}$ and $P_{2}$ and $P_{4}$ the pressure at the positions 1,2 and 4 respectively, $T_{3}$ the temperature at the position 3 and $m$ the mass flow. 
For the thermodynamic simulation, the values of enthalpy $\left(h_{1}, h_{3}, h_{5}\right)$, enthalpy of saturated liquid $\left(h_{4 \mathrm{f}}, h_{6 \mathrm{f}}\right)$, enthalpy of saturated vapor $\left(h_{4 \mathrm{~g}}, h_{6 \mathrm{~g}}\right)$, entropy $\left(S_{3}, S_{5}\right)$, entropy of saturated liquid $\left(S_{4 \mathrm{f}}, S_{6 \mathrm{f}}\right)$, entropy of saturated vapor $\left(S_{4 \mathrm{~g}}, S_{6 \mathrm{~g}}\right)$, and specific volume $\left(\mathrm{v}_{1}\right)\left(\mathrm{m}^{3} / \mathrm{kg}\right)$ were interpolated and/or taken from the thermodynamic tables (B.1.1., B.1.2., B.1.3., and B.1.4.) proposed by Borgnakke and Sonntag [29]. The specific heat at constant pressure $\left(C_{\mathrm{p}}\right)$ was interpolated from Table A-15 proposed by Çengel [30]. The remaining variables were calculated using Eq. (1) to Eq. (19) (Table 2).

TABLE 2. DESCRIPTION OF THE VARIABLES AND THE

EQUATIONS USED IN THE THERMODYNAMIC SIMULATION

\begin{tabular}{|c|c|c|}
\hline Variable & Equation & \\
\hline \multirow[t]{2}{*}{ Position 2} & $h_{2}=\frac{h_{2 \mathrm{~s}}-h_{1}}{\eta_{\mathrm{P}}}+h_{1}$ & (1) \\
\hline & $h_{2 \mathrm{~s}}=h_{1}+v_{1}\left(P_{2}-P_{1}\right)$ & (2) \\
\hline \multirow[t]{3}{*}{ Position 4} & $x_{2}=\frac{S_{3}-S_{4 \mathrm{f}}}{S_{4 \mathrm{~g}}-S_{4 \mathrm{f}}}$ & (3) \\
\hline & $h_{4}=-\eta_{\mathrm{T}} \cdot\left(h_{3}-h_{4 \mathrm{~s}}\right)+h_{3}$ & (4) \\
\hline & $h_{4 \mathrm{~s}}=x_{4} \cdot\left(h_{4 \mathrm{~g}}-h_{4 \mathrm{f}}\right)+h_{4 \mathrm{f}}$ & (5) \\
\hline \multirow[t]{3}{*}{ Position 6} & $x_{6}=\frac{S_{5}-S_{6 \mathrm{f}}}{S_{6 \mathrm{~g}}-S_{6 \mathrm{f}}}$ & (6) \\
\hline & $h_{6}=-\eta_{\mathrm{T}} \cdot\left(h_{5}-h_{6 \mathrm{~s}}\right)+h_{5}$ & (7) \\
\hline & $h_{6 \mathrm{~s}}=x_{6} \cdot\left(h_{6 \mathrm{~g}}-h_{6 \mathrm{ff}}\right)+h_{6 \mathrm{f}}$ & (8) \\
\hline Turbine 1 & $\dot{W}_{\mathrm{T} 1}=\frac{m}{3600} \cdot\left(h_{3}-h_{4}\right)$ & (9) \\
\hline Turbine 2 & $\dot{W}_{\mathrm{T} 2}=\frac{m}{3600} \cdot\left(h_{5}-h_{6}\right)$ & (10) \\
\hline Total Turbines & $\dot{W}_{\mathrm{T}}=\dot{W}_{\mathrm{T} 1}+\dot{W}_{\mathrm{T} 2}$ & (11) \\
\hline Evaporator 1 & $\dot{Q}_{\mathrm{in}, \mathrm{E} 1}=\dot{Q}_{\mathrm{in}, 2-3}+\dot{Q}_{\mathrm{in}, 4-5}$ & (12) \\
\hline Pump & $\dot{W}_{\mathrm{P}}=\frac{\dot{m}}{3600} \cdot\left(h_{2}-h_{1}\right)$ & (13) \\
\hline Condenser & $\dot{m}_{i}=\frac{\dot{m}}{3600} \cdot \frac{\left(h_{4 \mathrm{~s}}-h_{1}\right)}{C_{\mathrm{P}} \cdot\left(T_{\mathrm{B}}-T_{\mathrm{A}}\right)}$ & (14) \\
\hline Network Output & $\dot{W}_{\mathrm{n}}=\dot{W}_{\mathrm{T} 1}+\dot{W}_{\mathrm{T} 2}-\dot{W}_{\mathrm{P}}$ & (15) \\
\hline Efficiency of the cycle & $\eta_{\mathrm{cyc}}=\frac{\dot{W}_{\mathrm{n}}}{\dot{Q}_{\mathrm{in}, \mathrm{E} 1}}$ & (16) \\
\hline
\end{tabular}




$\begin{array}{ll}\text { Volume flow rate } & \dot{m}=\frac{\dot{Q}_{\mathrm{in} \mathrm{E} 1}}{\mathrm{LHV} \cdot \eta_{\mathrm{E} 1}} \\ \text { Efficiency of the power plant } & \eta_{\mathrm{P}}=\eta_{\mathrm{E} 1} \cdot \eta_{\mathrm{cyc}} \\ \text { FTE } & \mathrm{FTE}=\frac{1}{\eta_{\mathrm{P}}}\end{array}$

\subsection{Environmental Analysis}

This analysis uses qualitative and quantitative data to analyse the quality of groundwater in the surrounding areas of the incinerator and the landfill of the island. For this, data of the mass distribution and water supply network, potential of groundwater recharge and chemical status of groundwater in Terceira island were used.

\subsection{Economic Analysis}

This analysis uses as supporting data the financial statements report from 2014 to 2017 [31]-[34] of the municipal company of management and environmental valorisation of Terceira Island (responsible for the management of the landfill and incinerator).

To assess the sustainability of this investment Eq. (20)-(26) were used (Table 3). For the risk analysis, the Monte Carlo simulation of palisade @ risk tool was used. For this, the normal distribution was defined, and the simulation was performed with 500 iterations and 10 simulations.

\section{TABLE 3. EQUATIONS USED IN THE ECONOMIC SIMULATION}

\begin{tabular}{lll}
\hline Variable & Equation \\
\hline Total outflow & Total operating costs + total investment costs \\
Net income & Total inflow - total outflow & $(20)$ \\
Total inflow & Funding sources + investment profitability \\
Total outflow & Operating costs + investment costs + interest rate + provision \\
Total cash flow & Inflow + total outflow \\
Cumulative cash flow & [total cash flow $]_{n}+[\text { cumulative cash flow }]_{n}-1$ \\
NPV & $\sum_{t=0}^{n} a_{\mathrm{t}} S_{\mathrm{t}}=\frac{S_{0}}{(1+i)^{0}}+\frac{S_{1}}{(1+i)^{1}}+\ldots+\frac{n}{(1+i)^{n}}$ \\
&
\end{tabular}

\section{RESUlts AND Discussion}

\subsection{Thermodynamic Modelling and Simulation}

The results of the thermodynamic simulation are illustrated in Table 4. As it can be seen, for an initial mass flow of 19727 tonnes, the net rate of work is $485 \mathrm{~kW}$, the efficiency of the cycle is $21 \%$ and the efficiency of the power plant (19\%). Similar results have been reported Desideri et al. and Lei et al. [35], [36]. 
TABLE 4. Results of the THERMODYNAMiC MODELLING AND Simulation

\begin{tabular}{llllllll}
\hline Parameter & $\dot{W}_{\mathrm{n}}$ & LHV & $\dot{m}$ & FTE & $\eta_{\text {cyc }}$ & $\eta_{\mathrm{E} 1}$ & $\eta_{\mathrm{P}}$ \\
\hline Results & 485 & 1591257 & 0.00136 & 4.5 & 0.25 & 0.9 & 0.22 \\
\hline
\end{tabular}

Fig. 5 illustrates the variation of the turbine power output with temperature. As can be seen, the net output increases linearly with the increment of the temperature. When the temperature increases from 100 to $150{ }^{\circ} \mathrm{C}$, the net output keeps rising from 609.92 to $679.3 \mathrm{~kW}$, respectively. These results are sustained by $\mathrm{Li}$ et al. [37]. The authors found that for temperatures range from $145-155^{\circ} \mathrm{C}$ the power of the turbine increases.

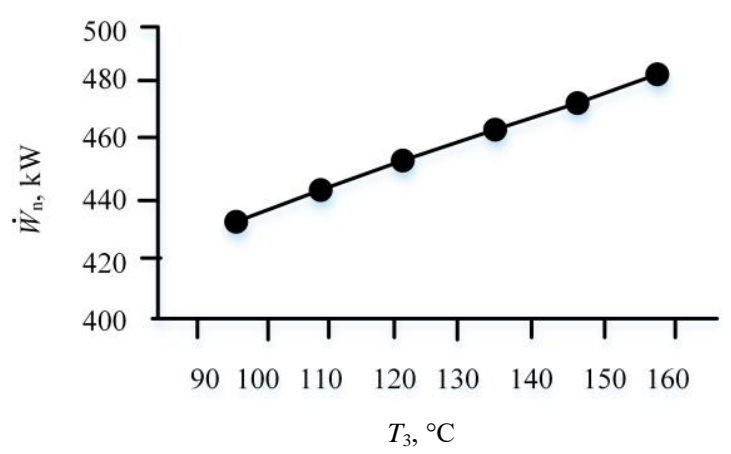

Fig. 3. Variation of net power output with temperature.

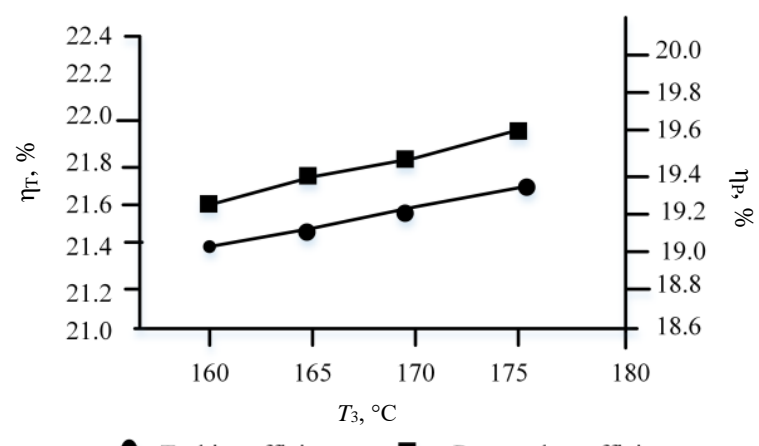

Turbine efficiency

Power plant efficiency

Fig. 4. Variation of turbines and power plant efficiency with temperature.

In Fig. 6 it can be seen how the performance of the turbines and of the system is affected by the temperature. The efficiency of the turbines increases, from $21.4 \%$ to $21.7 \%$ when the temperature increases from 160 to $175{ }^{\circ} \mathrm{C}$ and the efficiency of the power plant increases from $19.2 \%$ to $19.6 \%$ for the same temperature variation. Even though both efficiencies (turbine and power plant) increase, this change is less than $1 \%$. A study carried out by Li et al. [37] supports the results obtained. The authors justify this low range of efficiencies with the low-pressure ratio in the turbines caused by a pressure drop in the turbine outlet and in the condenser inlet. Similar results have also been reported by Li et al. [38], where the efficiency of the cycle increased linearly with the change in the temperature. 
Overall, increasing the average temperature can improve the thermal efficiency of the cycle [39].

Fig. 7 illustrates the variation of fuel to electricity ratio (FTE) with temperature. As can be seen, when the temperature increases, the FTE increases from 4.1 to 4.5 . Fig. 8 shows the variation of the net power output with pressure. When the pressure varies from 0.5 to $3.0 \mathrm{MPa}$, the net power output increases from 226 to $395 \mathrm{~kW}$, respectively. These observations were also reported by Usman et al. [40]. Overall, this increase with the pressure can be explained by the temperature of the working fluid because the higher the temperature of the working fluid, the higher the net power output and the higher the pressure ratio of the turbine.

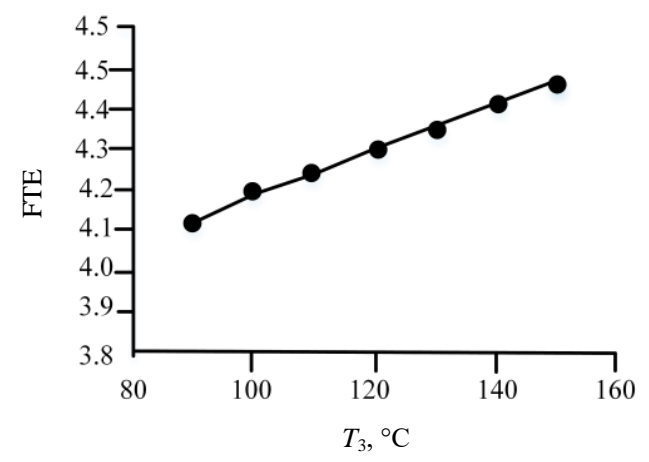

Fig. 5. Variation of FTE with temperature.

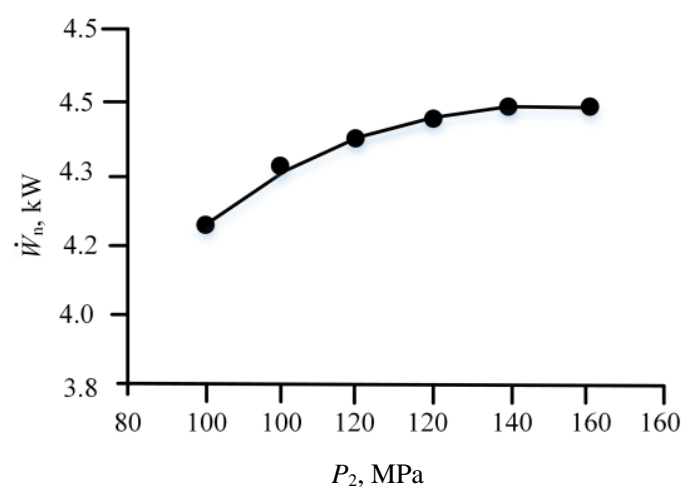

Fig. 6. Variation of net power output with pressure.

The relationship between the efficiencies of the power plant and the turbines with the pressure are displayed in Fig. 9. As observed, the pressure exhibits a positive effect on both efficiencies. It increases with the increment of the pressure. When the pressure varies from 0.50 to $3.0 \mathrm{MPa}$, the efficiency of the power plant increases from $12 \%$ to a maximum of $19 \%$, and it decreases to $18.89 \%$ when the pressure reaches $3.5 \mathrm{MPa}$. Regarding the efficiency of the turbine, it increases from $13 \%$ to a maximum of $21 \%$ when the pressure varies between 0.50 and 3.0 MPa, and it decreases to $20.99 \%$ when the pressure reaches 3.5 MPa. Mago et al. and Wu reported similar conclusions [18], [39]. The authors concluded that the higher the pressure, the higher the network and the higher the thermal efficiency. 


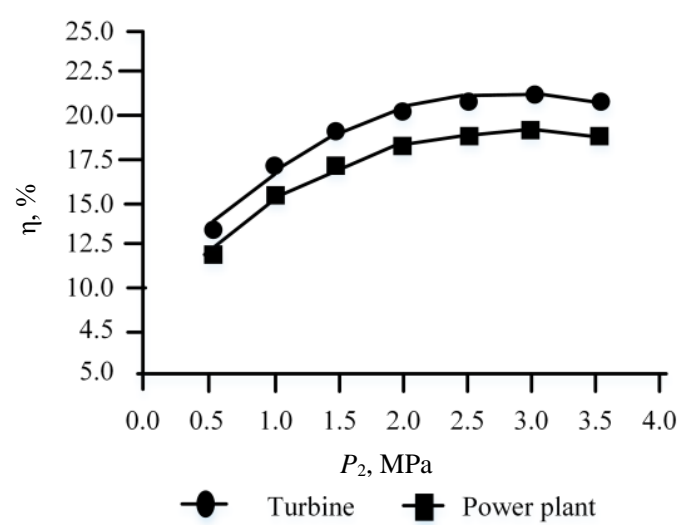

Fig. 7. Variation of the efficiency of the turbine and the power plant with pressure.

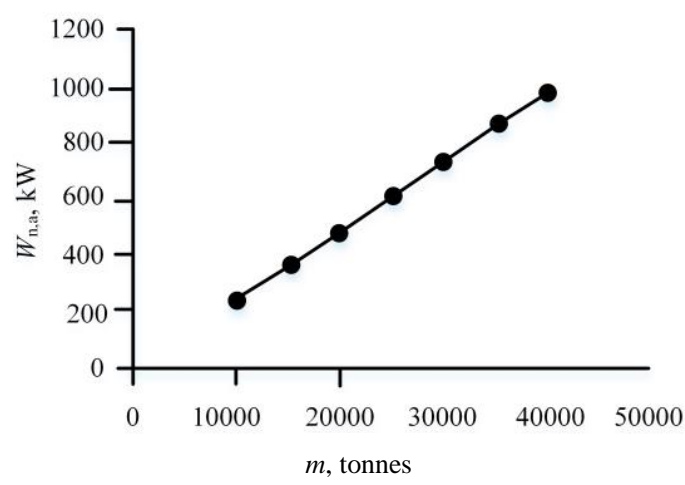

Fig. 8. Variation of net power output with mass flow.

The relationship between the net power output and the mass flow is plotted in Fig. 10. The graph shows a linear evolution of the net power output from 246 to $984 \mathrm{~kW}$, with the increase of the mass flow from 10000 tons to 40000 tonnes, respectively. A study carried out by Pang et al. [41] reveals a similar relationship between mass flow and power consumption.

\subsection{Environmental Analysis}

Fig. 11 illustrates the water masses distribution and water points for supply of Terceira island. The island has 36 water collection points $\left(0.09\right.$ collection points $\left./ \mathrm{km}^{2}\right)$ supplied by 229 springs $\left(0.57\right.$ springs $\left./ \mathrm{km}^{2}\right)$. As it can be seen from the figure, the landfill and the incinerator are in the intersection of three water masses (central, Ribeirinha and Caldeira Guilherme Moniz), that supply water to many collection points. The springs are mainly located in the Labaçal - Quatro Ribeiras, Santa Bárbara Inferior, Central and Caldeira Guilherme Moniz water masses, while the water collection points are mainly in Caldeira de Guilherme Moniz, Graben and Ignimbrito Lajes [42]. 


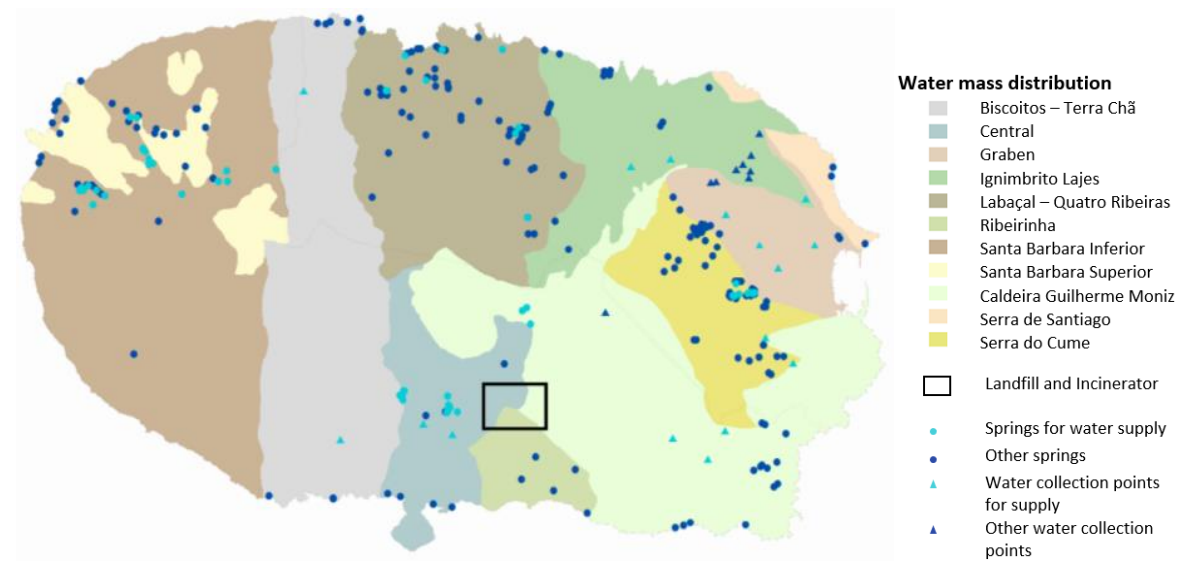

Fig. 11. Water mass distribution and water supply network in Terceira Island [43].

The water resources (groundwater) of Terceira represent $193.1 \mathrm{hm}^{3} /$ year from which, $56.7 \mathrm{hm}^{3} /$ year comes from the water mass Caldeira Guilherme Moniz, and $39.1 \mathrm{hm}^{3} /$ year from the water mass Biscoitos - Terra Chã [42]. This data illustrates the importance of water protection specifically in case of the water masses surrounding the landfill, to ensure water quality for human consumption.

The potential of groundwater recharge in the different water masses in Terceira Island is represented in Fig. 12. As it can be seen, the potential of groundwater recharge is higher in

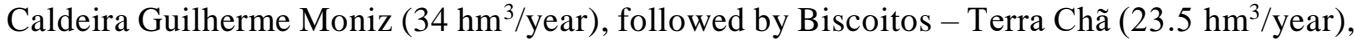
Labaçal - Quatro Ribeiras (15.6 hm³/year), Santa Bárbara Inferior (14.7 $\mathrm{hm}^{3} /$ year), Santa Bárbara Superior (7.4 $\mathrm{hm}^{3} /$ year), Ignimbrito Lajes $\left(6.3 \mathrm{hm}^{3} /\right.$ year), Central $\left(4.5 \mathrm{hm}^{3} /\right.$ year), Serra do Cume (4.2 $\mathrm{hm}^{3} /$ year), Graben $\left(2.7 \mathrm{hm}^{3} /\right.$ year $)$, Ribeirinha $\left(2.1 \mathrm{hm}^{3} /\right.$ year $)$ and Serra de Santiago (0.94 $\mathrm{hm}^{3} /$ year) [42].

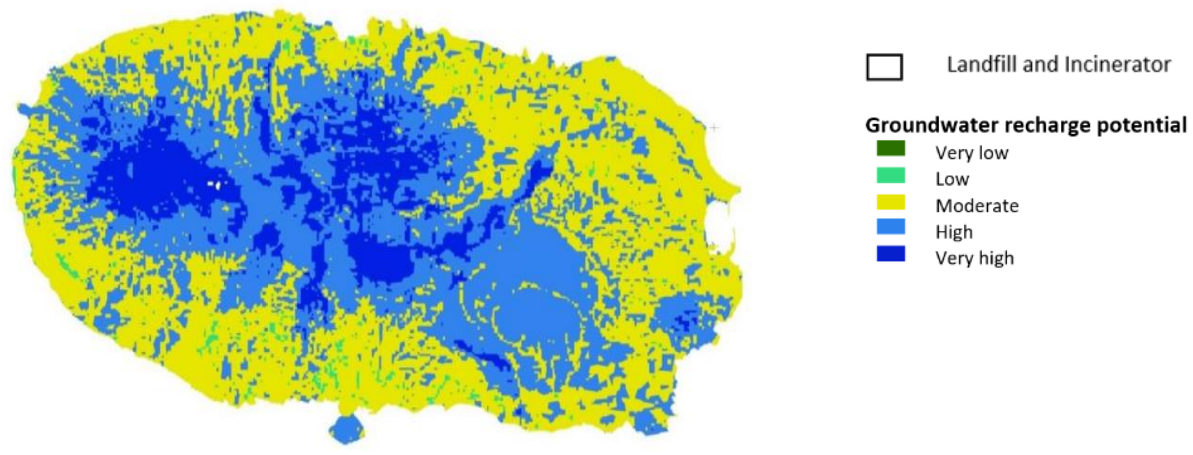

Fig. 12. Potential of groundwater recharge in Terceira Island [44].

From the environmental perspective, the landfill and the incinerator are in a sensitive area of groundwater recharge. According to Rahmasary et al. [45] landfills often lack appropriate sealing to prevent leaking. In the case of rupture of the sealing cells of the solid waste landfill, the local groundwater supplies will be contaminated, the water will be unfit for human consumption, and the natural recharge of the water mass will not be enough to 
neutralize the problem, since the recharge potential in this area is relatively low (2.1-4.5 $\mathrm{hm}^{3} /$ year). However, a study by Machado [46] shows that at that time the groundwater in this area was not affected by the proximity to the landfill and that the water from the collection point in this area was not used for human consumption.

The overall status of the groundwater quality in Terceira was analysed by the Government of the Azores. Table 5 shows the chemical status of groundwater in Terceira Island. The chemical analysis performed at all the groundwater masses of the island revealed that they are in good condition. Just three values have been reported above the acceptable levels, but none of these is in the area adjacent to the landfill. Quantitative and chemical data show that the quality of the groundwater of the island is 'Good' (the classification system 'Good' or 'Poor' is established in the Directive 2000/60/EC of the European Parliament and of the Council in the field of water policy [47]).

Even though there are no apparent impacts for human consumption, removing the sealing cells at the landfill (through incineration) will drastically reduce the risk of contamination of the groundwater supplies, and it will give room for soil recovery.

\subsection{Economic Analysis}

The results of the economic analysis are represented in Table 6, and include the total investment costs, operating costs, investment profitability, funding sources, financial sustainability, return on capital invested, and net present value, from the year of construction until the year 2033. The investment costs are done essentially on the first year with the construction of the incinerator (-35 383920 EUR). As it can be seen from the table, the operating costs in the year 2014 represent nearly $64 \%$ of the total operating costs, $56 \%$ in 2015 and $25 \%$ between 2016-2033. The staff and administrative expenditure represent approximately $20 \%$ of the total operating costs. Regarding the investment profitability, it includes the revenue from the sale of energy to the Electricity of the Azores knowing that in the year of 2016, the energy produced by the incinerator was $10255 \mathrm{MWh}$ year and that the electricity was bought at $96 € / \mathrm{MW}(0.096 € / \mathrm{kW})$. Also, it should be considered that the plant was in the test phase in the year 2015, justifying the difference in the sales and services between the years 2015 and 2016. The cash flow of the project is positive just in the year 2016 due to the funding sources used to pay the construction expenses. The project is not profitable since the net present value is negative (-17 518112.87 EUR). Chang and Davila [48] also analysed the investment costs of incineration construction. The authors concluded that incineration facilities have very high investment costs making it less competitive than residues deposit in the landfills. It was proposed a public-private partnership as a solution the high investment costs reported in this type of projects.

Fig. 13 represents the probability distribution of the investment, with a normal distribution. The model indicates that $90 \%$ of the net present values are probable to occur between $-23010752.54 €$ and $-12322025.03 €$. The mean of the net present value is $-17518036.90 €$. 


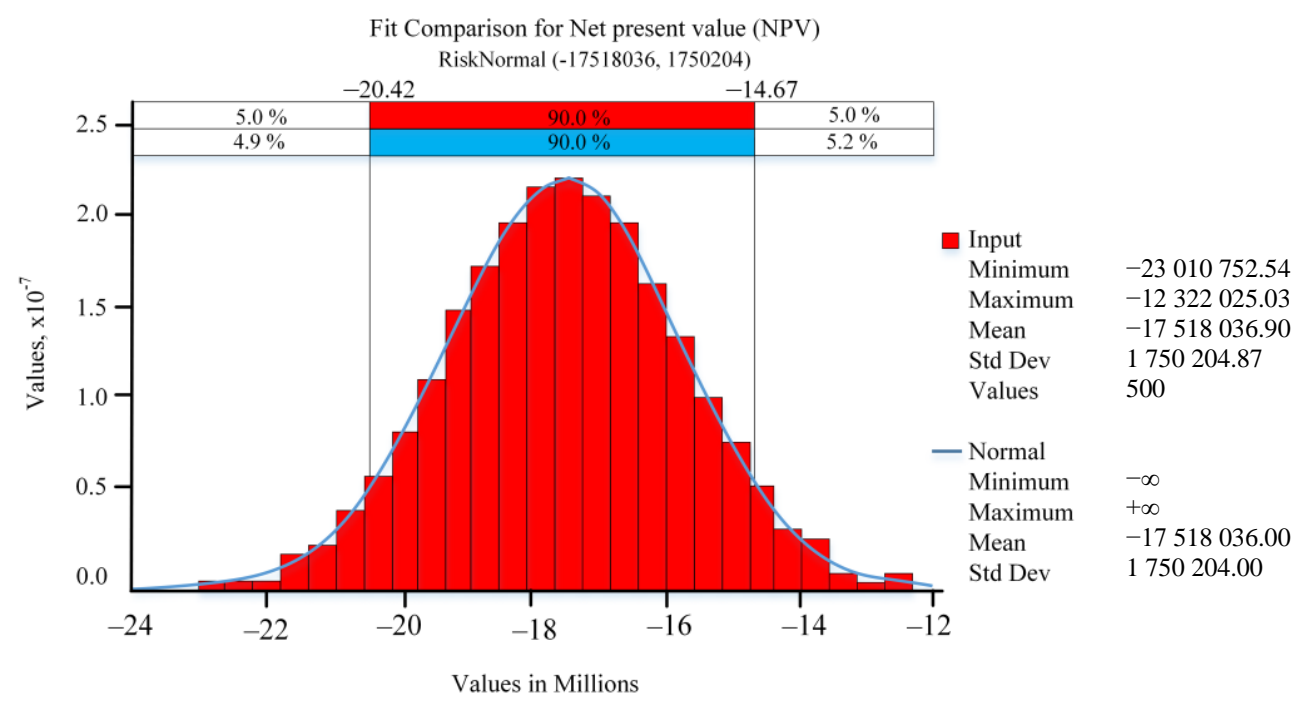

Fig. 13. Probability distribution of the investment.

Even though the project has energetic potential, it seems over-dimensioned for the size of the island, making it economically inviable. At the moment, the operating costs exceed the revenue obtained from the sale of energy, making the project highly inviable. There is a need for strategies to reduce operating costs and increase revenue. There are many residues deposited in the landfill that can be used for the production and sale of energy or even the utilization of residues from other islands of the archipelago. However, it is very unlikely that this project will be profitable in its lifetime because the island has a limited capacity for energy that can be injected into the grid. The major solution for this problem would have been proper planning and the construction of a smaller power plant that would have smaller operating costs and would partially reduce the losses of the project. Despite the project not being economically feasible (due to the operation costs), studies of this nature are essential to ensure appropriate planning of cogeneration systems. The main conclusion that can be drawn from this study is that the project was not properly planned. If studies of this nature had been carried out before, the central could have been economically profitable. Despite the energetic potential of the power plant, and the environmental advantages of its implementation, its technical specifications (size) make it unviable. 
TABLE 3. CHEMICAL STATUS OF GROUNDWATER IN TERCEIRA ISLAND (ADAPTED [49])

\begin{tabular}{|c|c|c|c|c|c|c|c|c|c|c|c|c|}
\hline $\begin{array}{l}\text { Groundwater } \\
\text { mass }\end{array}$ & $\begin{array}{l}\text { Collection } \\
\text { Point ID }\end{array}$ & $\begin{array}{l}\mathrm{NH}_{4}, \\
\mathrm{mg} / \mathrm{L}\end{array}$ & As, $\mathrm{mg} / \mathrm{L}$ & $\mathrm{Cd}, \mathrm{mg} / \mathrm{L}$ & $\mathrm{Pb}, \mathrm{mg} / \mathrm{L}$ & $\mathrm{Cl}, \mathrm{mg} / \mathrm{L}$ & $\begin{array}{l}\text { Cond., } \\
\mu \mathrm{S} / \mathrm{cm}\end{array}$ & $\mathrm{Hg}, \mathrm{mg} / \mathrm{L}$ & $\begin{array}{l}\mathrm{NO}_{3}, \\
\mathrm{mg} / \mathrm{L}\end{array}$ & $\mathrm{pH}$ & $\mathrm{SO}_{4}, \mathrm{mg} / \mathrm{L}$ & Status \\
\hline \multirow{2}{*}{$\begin{array}{l}\text { Biscoitos - } \\
\text { Terra Chã }\end{array}$} & TER.238 & 13.8 & 13.4 & 0.2 & 2.38 & 91.75 & 569 & 0.2 & 5.34 & 6.5 & 42.04 & \multirow{2}{*}{ Good } \\
\hline & TER.260 & 10.0 & 2.4 & 0.1 & 1.25 & 16.50 & 211 & 2.5 & 5.00 & 5.9 & 4.55 & \\
\hline \multirow{3}{*}{$\begin{array}{l}\text { Caldeira } \\
\text { Guilherme } \\
\text { Moniz }\end{array}$} & TER.41 & 16.3 & 1.3 & 0.2 & 2.38 & 15.40 & 119 & 0.2 & 3.40 & 7.2 & 4.01 & \multirow{3}{*}{ Good } \\
\hline & TER.42 & 13.8 & 1.3 & 0.2 & 2.38 & 15.20 & 128 & 0.1 & 2.73 & 7.2 & 3.59 & \\
\hline & TER.236 & 23.8 & 1.3 & 0.5 & 3.06 & 30.88 & 204 & 0.2 & 23.63 & 7.1 & 7.28 & \\
\hline \multirow{2}{*}{ Central } & TER.30 & 12.5 & 1.3 & 0.2 & 2.38 & 22.80 & 126 & 0.1 & 11.13 & 6.6 & 3.90 & \multirow{2}{*}{ Good } \\
\hline & TER.55 & 13.8 & 1.3 & 0.2 & 2.38 & 22.40 & 141 & 0.1 & 4.95 & 6.9 & 3.98 & \\
\hline \multirow{2}{*}{ Graben } & TER.231 & 15.0 & 1.3 & 0.2 & 2.38 & 165.13 & 637 & 0.2 & 23.75 & 7.6 & 19.38 & \multirow{2}{*}{ Good } \\
\hline & TER.234 & 13.8 & 1.3 & 0.2 & 2.38 & 340.38 & 1136 & 0.1 & 11.00 & 7.5 & 34.75 & \\
\hline $\begin{array}{l}\text { Ignimbrito } \\
\text { Lajes }\end{array}$ & TER.233 & 15.0 & 1.5 & 0.2 & 2.38 & 155.00 & 629 & 0.2 & 10.95 & 6.9 & 16.34 & Good \\
\hline \multirow{3}{*}{$\begin{array}{l}\text { Labaçal - } \\
\text { Quatro } \\
\text { Ribeiras }\end{array}$} & TER.3 & 13.8 & 1.3 & 0.2 & 2.38 & 41.80 & 249 & 0.1 & 27.50 & 7.4 & 8.18 & \multirow{3}{*}{ Good } \\
\hline & TER.38 & 15.0 & 2.4 & 0.2 & 2.38 & 18.20 & 184 & 0.1 & 4.19 & 8.1 & 4.25 & \\
\hline & TER.54 & 13.8 & 1.5 & 0.2 & 2.38 & 24.40 & 175 & 0.1 & 15.38 & 7.0 & 6.41 & \\
\hline \multirow{3}{*}{$\begin{array}{l}\text { Santa } \\
\text { Bárbara } \\
\text { Inferior }\end{array}$} & TER.18 & 20.0 & 1.3 & 0.2 & 2.17 & 35.67 & 189 & 0.1 & 15.67 & 7.0 & 8.27 & \multirow{3}{*}{ Good } \\
\hline & TER.21 & 15.0 & 1.2 & 0.2 & 2.17 & 17.33 & 212 & 0.1 & 12.33 & 7.1 & 3.90 & \\
\hline & TER.22 & 15.0 & 1.3 & 0.3 & 2.38 & 18.20 & 96 & 0.1 & 2.25 & 6.6 & 3.13 & \\
\hline \multirow{2}{*}{$\begin{array}{l}\text { Serra do } \\
\text { Cume }\end{array}$} & TER.15 & 15.0 & 1.5 & 0.2 & 2.38 & 24.2 & 177 & 0.1 & 22.38 & 7.6 & 3.79 & \multirow{2}{*}{ Good } \\
\hline & TER.230 & 18.3 & 1.3 & 0.2 & 2.38 & 177.50 & 646 & 0.2 & 7.55 & 7.7 & 19.36 & \\
\hline \multicolumn{2}{|l|}{ Safety value } & 450 & 9 & 4.5 & 9 & 225 & 2250 & 0.9 & 45 & $5.5-9$ & 225 & - \\
\hline \multicolumn{2}{|c|}{ Maximum allowed } & 500 & 10 & 5 & 10 & 250 & 2500 & 1 & 50 & $5.5-9$ & 250 & - \\
\hline
\end{tabular}


TABle 4. FinANCIAL SUSTAINABILITY AND RETURN ON CAPITAL (EUR)

\begin{tabular}{|c|c|c|c|c|}
\hline Description & 2014 & 2015 & 2016 & $2017-2033$ \\
\hline \multicolumn{5}{|l|}{ Total investment } \\
\hline Construction of incinerator & -35383920 & 0 & 0 & 0 \\
\hline \multicolumn{5}{|l|}{ Operating costs } \\
\hline Operating costs & -477653 & -668272 & -780343 & -859492 \\
\hline Staff and administrative expenditure & -149477 & -200911 & -623014 & -683837 \\
\hline Consumables and supplies & 0 & 0 & -308482 & -460469 \\
\hline Impairment of receivables & 0 & -120 & -38 & -19 \\
\hline Reductions in the fair value & 0 & -85 & -239 & -1759 \\
\hline Other operating costs & -37744 & -77263 & -67311 & -37137 \\
\hline Reversals of depreciation and amortization & -23563 & -202239 & -1311282 & -1411624 \\
\hline Interest rate & -40859 & -37472 & -63604 & -110062 \\
\hline Income tax & -17549 & -1598 & -1299 & -1162 \\
\hline \multicolumn{5}{|l|}{ Investment profitability } \\
\hline Sales and services & 748941 & 754019 & 1881888 & 1734244 \\
\hline Grants & 3000 & 1250 & 10094 & 18333 \\
\hline Other operating income & 83624 & 435210 & 1277503 & 1295482 \\
\hline Increase in the fair value & 0 & 0 & 0 & 0 \\
\hline \multicolumn{5}{|l|}{ Funding sources } \\
\hline Loan & 5000000 & 0 & 0 & 0 \\
\hline Investment subsidy & 0 & 0 & 35383920 & 0 \\
\hline \multicolumn{5}{|l|}{ Financial sustainability and return on capital } \\
\hline Funding sources & 5000000 & 0 & 35383920 & 0 \\
\hline Investment profitability & 835565 & 1190480 & 3169486 & 1734244 \\
\hline Total inflow & 5835565 & 1190480 & 38553406 & 1734244 \\
\hline Operating costs & -746846 & -1187960 & -3155612 & -3565561 \\
\hline Investment costs & -35383920 & 0 & 0 & 0 \\
\hline Interest rate & -300000 & -272727 & -245455 & -218182 \\
\hline Provision & -754545 & -727273 & -700000 & -672727 \\
\hline Total outflow & -37185312 & -2187960 & -4101067 & -4456470 \\
\hline Total cashflow & -31349747 & -997481 & 34452339 & -2722226 \\
\hline Cumulative cash flow & -31349747 & -32347227 & 2105111 & -617114 \\
\hline Net present value (NPV) & & & & -22427394 \\
\hline
\end{tabular}




\section{Conclusions}

This paper develops and simulates a thermodynamic, environmental and economic model of an ORC for urban waste recovery, using R245fa as a working fluid. It also investigates the effects of temperature, pressure and mass flow on net output, the efficiency of the power plant, mass flow rate and FTE. The results show that with a yearly mass supply of 19727 tonnes it is possible to produce $485 \mathrm{~kW}$ of energy and have a maximum efficiency of the cycle of $25 \%$. From an energetic point of view, ORC is a promising solution for electricity production on Terceira Island (Azores, Portugal). It can also be used as an environmental solution to the large number of urban wastes deposited in the landfill, and as a strategy leading to a low carbon society. However, the economic analysis in this study indicates that the construction of an incinerator in Terceira Island is not self-sustainable. Its losses exceed to 500000.00 EUR per year.

Studies of this nature are essential to ensure the technical and economic viability of a cogeneration system. Upcoming work can include the development and exploitation of this model, namely the use of different working fluids and its applications in other isolated areas. Also, this study can be further developed from the economic perspective, to analyse solutions to minimize the economic losses of the incinerator constructed in Terceira Island and to provide a supporting tool to decision makers.

\section{ACKNOWLEDGEMENT}

Publication is supported by the European Union, European Regional Development Fund (Estonian University of Life Sciences ASTRA project "Value-chain based bio-economy" Doctoral School of Energy and Geotechnology III).

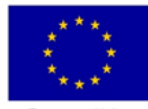

European Union European Regional
Development Fund

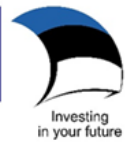

\section{REFERENCES}

[1] International Energy Agency. Key world energy statistics, 2017. [Online]. Available: https://www.iea.org/publications/freepublications/publication/KeyWorld2017.pdf

[2] Rocha-Meneses L., et al. The effect of flue gas explosive decompression pretreatment on methane recovery from bioethanol production waste. Industrial Crops and Products 2019:127:66-72. doi:10.1016/j.indcrop.2018.10.057

[3] Ion I. V., Ciocea G., Popescu F. Energy saving and GHG emission reduction in a micro-CCHP system by use of solar energy. Environmental and Climate Technologies 2012:10(1):16-20. doi:10.2478/v10145-012-0020-Z

[4] Rocha-Meneses, L. The preferences of domestic consumers of electricity in Terceira Island (As preferências dos consumidores domésticos de eletricidade na ilha Terceira). 10.13140/RG.2.1.3169.1926., 2015 doi:10.13140/RG.2.1.3169.1926

[5] Rocha-Meneses L., et al. Second-generation bioethanol production: A review of strategies for waste valorisation. Agronomy Research 2017:15(3):830-847.

[6] Rocha-Meneses L., et al. Potential of bioethanol production waste for methane recovery. Energy 2019:173:133-139. doi:10.1016/j.energy.2019.02.073

[7] van Leeuwen K., et al. The energy \& raw materials factory: Role and potential contribution to the circular economy of the Netherlands. Environmental Management 2018:61(5):786-795. doi:10.1007/s00267-018-0995-8

[8] Lecompte S., et al. Case Study of an Organic Rankine Cycle (ORC) for Waste Heat Recovery from an Electric Arc Furnace (EAF). Energies 2017:10(5):649. doi:10.3390/en10050649

[9] Cimdina G., et al. Methodologies used for scaling-up from a single energy production unit to state energy sector. Environmental and Climate Technologies 2015:15(1):5-21. doi:10.1515/rtuect-2015-0002

[10] Heberle F., Brüggemann D. Thermo-Economic Analysis of Zeotropic Mixtures and Pure Working Fluids in Organic Rankine Cycles for Waste Heat Recovery. Energies 2016:9(4):226. doi:10.3390/en9040226

[11] Fiksel J., Lal R. Transforming waste into resources for the Indian economy. Environmental Development 2018:26:123128. doi:10.1016/j.envdev.2018.02.002

[12] Quoilin S., et al. Techno-economic survey of Organic Rankine Cycle (ORC) systems. Renewable and Sustainable Energy Reviews 2013:22:168-186. doi:10.1016/j.rser.2013.01.028 
[13] Karellas S., Schuster A. Supercritical fluid parameters in organic rankine cycle applications. International Journal of Thermodynamics 2008:11(3):101-108.

[14] Carlão R. L. L. Projecto de um ciclo de Rankine orgânico para produção de 200 kWe. (Project of an Organic Rankine for $200 \mathrm{kWe}$ production) (in Pportuguese). Engenharia. Universidade do Porto, 2009. [Online]. Available: http://hdl.handle.net/10216/59624.

[15] Liu X., Zhang Y., Shen J. System performance optimization of ORC-based geo-plant with R245fa under different geothermal water inlet temperatures. Geothermics 2017:66:134-142. doi:10.1016/j.geothermics.2016.12.004

[16] Xu W., et al. Novel experimental research on the compression process in organic Rankine cycle (ORC). Energy Conversion and Management 2017:137:1-11. doi:10.1016/j.enconman.2017.01.025

[17] Wang J., et al. Performance enhancement of organic Rankine cycle with two-stage evaporation using energy and exergy analyses. Geothermics 2017:65:126-134. doi:10.1016/j.geothermics.2016.09.005

[18] Mago P. J., et al. An examination of regenerative organic Rankine cycles using dry fluids. Applied Thermal Engineering 2008:28(8-9):998-1007. doi:10.1016/j.applthermaleng.2007.06.025

[19] Li X., Liu T., Chen L. Thermodynamic Performance Analysis of an Improved Two-Stage Organic Rankine Cycle. Energies 2018:11(11):2864. doi:10.3390/en11112864

[20] Li T., et al. Performance improvement of two-stage serial organic Rankine cycle (TSORC) driven by dual-level heat sources of geothermal energy coupled with solar energy. Geothermics 2018:76:261-270. doi:10.1016/j.geothermics.2018.07.010

[21] Rech S., et al. Design and off-design models of single and two-stage ORC systems on board a LNG carrier for the search of the optimal performance and control strategy. Applied Energy 2017:204:221-241. doi:10.1016/j.apenergy.2017.06.103

[22] Statistics Azores. CENSUS 2011 - Final Results of Autonomous Region of the Azores (parish) (CENSUS 2011 Resultados definitivos da Região Autónoma dos Açores (freguesia)) (in Portuguese). [Online]. Available: http://srea.azores.gov.pt

[23] Electricidade dos Açores. Production and consumption (Produção e consumo) (in Portuguese). [Online]. Available: https://www.eda.pt

[24] Secretaria Regional do Ambiente e do Mar. Report Urban waste in Terceira Island (Relatório Residuos Urbanos - Ilha Terceira) (in Portuguese). Governo Regional dos Açores. Secretaria Regional da Agricultura e Ambiente. Direção Regional do Ambiente. [Online]. Available: http://www.azores.gov.pt/GRA/srrn-residuos

[25] Kusuda E., Morisaki T., Ikegami Y. Performance Test of Double-stage Rankine Cycle Experimental Plant for OTEC. Procedia Engineering 2015:105:713-718. doi:10.1016/j.proeng.2015.05.061

[26] Andreasen J. G., Meroni A., Haglind F. A Comparison of Organic and Steam Rankine Cycle Power Systems for Waste Heat Recovery on Large Ships. Energies 2017:10(4):547. doi:10.3390/en10040547

[27] Liu S., et al. Experimental Study on R245fa Condensation Heat Transfer Properties in Horizontal Tube. Energy Procedia 2016:104:419-424. doi:10.1016/j.egypro.2016.12.071

[28] Kaynakli O., et al. Thermodynamic analysis of the organic rankine cycle and the effect of refrigerant selection on cycle performance. International Journal of Energy Applications and Technologies 2017:4(4):101-108.

[29] Borgnakke C., Sonntag R. E. Fundamentals of Thermodynamics, 8th Edition. United States of America: John Wiley \& Sons, Inc., 2013.

[30] Çengel Y. A. Introduction to Thermodynamics and Heat Transfer, 2nd Edition. United States of America: The McGraw-Hill, 2008.

[31] Teramb - Empresa Municipal de Gestão e Valorização Ambiental da ilha Terceira EM. Annual Report and Accounts. (Relatório de Gestão e contas 2014) (in Portuguese), 2014.

[32] Teramb - Empresa Municipal de Gestão e Valorização Ambiental da ilha Terceira EM. Annual Report and Accounts. (Relatório de Gestão e contas 2015) (in Portuguese), 2015.

[33] Teramb - Empresa Municipal de Gestão e Valorização Ambiental da ilha Terceira EM. Annual Report and Accounts. (Relatório de Gestão e contas 2016) (in Portuguese), 2016.

[34] Teramb - Empresa Municipal de Gestão e Valorização Ambiental da ilha Terceira EM. Annual Report and Accounts. (Relatório de Gestão e contas 2017) (in Portuguese), 2017.

[35] Desideri A., et al. Experimental comparison of organic fluids for low temperature ORC (organic Rankine cycle) systems for waste heat recovery applications. Energy 2016:97:460-469. doi:10.1016/j.energy.2015.12.012

[36] Lei B., et al. Experimental study and theoretical analysis of a Roto-Jet pump in small scale organic Rankine cycles. Energy Conversion and Management 2016:111:198-204. doi:10.1016/i.enconman.2015.12.062

[37] Li L., et al. Experimental investigations into power generation with low grade waste heat and R245fa Organic Rankine Cycles (ORCs). Applied Thermal Engineering 2017:115:815-824. doi:10.1016/j.applthermaleng.2017.01.024

[38] Li J., et al. Modelling of organic Rankine cycle efficiency with respect to the equivalent hot side temperature. Energy 2016:115(1):668-683. doi:10.1016/j.energy.2016.09.049

[39] Wu C. Thermodynamics and Heat Powered Cycles: A Cognitive Engineering Approach. Nova Science Publishers, 2011. 
[40] Usman M., et al. Thermo-economic comparison of air-cooled and cooling tower based Organic Rankine Cycle (ORC) with R245fa and R1233zde as candidate working fluids for different geographical climate conditions. Energy 2017:123:353-366. doi:10.1016/j.energy.2017.01.134

[41] Pang K.-C., et al. Experimental study on organic Rankine cycle utilizing R245fa, R123 and their mixtures to investigate the maximum power generation from low-grade heat. Energy 2017:133(C):636-651. doi:10.1016/j.energy.2017.05.128

[42] Freire P. A. T. Recursos hidrominerais dos Açores: hidrogeologia e avaliação do potencial sócioeconómico. (Hydromineral resources of the Azores: hydrogeology and evaluation of the socioeconomic potential) (in Portuguese). Ponta Delgada: Universidade dos Açores, 2013.

[43] Direção Regional do Ambiente (Governo dos Açores). Regional water information system (Sistema Regional de Informação sobre a Água) (in Portuguese). [Online]. Available: http://sig-sraa.azores.gov.pt

[44] Direção Regional do Ambiente (Governo dos Açores). PGRH-AÇORES 2016-2021 Technical Report, Characterization and Diagnosis (Relatório Técnico, Caracterização e Diagnóstico - Terceira) (in Portuguese). 2015.

[45] Rahmasary A. N., et al. Overcoming the Challenges of Water, Waste and Climate Change in Asian Cities. Environmental Management 2019:63(4):520-535. doi:10.1007/s00267-019-01137-y

[46] Machado J. H. M. Management and conservation of water supply in the county of Angra do Heroísmo (Gestão e conservação de captações de água para abastecimento no concelho de Angra do Heroísmo) (in Portuguese). Angra do Heró́smo: Universidade dos Açores. XIX, 177 f. Dissertação de Mestrado. [Online]. Available: http://hdl.handle.net/10400.3/1558.

[47] Directive 2000/60/EC of 23 October 2000 establishing a framework for Community action in the field of water policy. Official Journal of the European Communities 2000:L327.

[48] Chang N.-B., Davila E. J. E. M. Siting and Routing Assessment for Solid Waste Management Under Uncertainty Using the Grey Mini-Max Regret Criterion. Environmental Management 2006:38(4):654-672. doi:10.1007/s00267-005-0292-1

[49] Governo dos Açores. Management Plan of the Hydrographic Region of the Azores (PGRH-Azores 2016-2021) (Plano de Gestão da Região Hidrográfica dos Açores 2016-2021 (PGRH-Açores 2016-2021)) (in Portuguese). [Online]. Available: http://servicos-sraa.azores.gov.pt 